apuntesuniversitarios.upeu.edu.pe

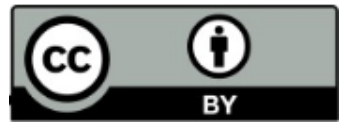

Apuntes Universitarios, 2021: 11(1), enero-marzo

ISSN: 2304-0335 DOI: https://doi.org/10.17162/au.v11i1.570

\title{
Análisis educacional sobre la protección jurídica de las invenciones en la Unión Europea: pasado y presente
}

\section{An educational analysis on the legal protection of inventions in the European Union: past and present}

\author{
Ksenia Michailovna Belikova ${ }^{1 \mathrm{a}}$ \\ Peoples’ Friendship University of Russia (RUDN University), Moscow, Russia ${ }^{1}$
}

Orcid ID: https://orcid.org/0000-0001-8068-1616 ${ }^{1}$

Recibido: 06 de junio de 2020

Aceptado: 10 de octubre de 2020

\begin{abstract}
Resumen
Este artículo tiene como objetivo explorar las novedades en la protección legal de invenciones en la Unión Europea (UE) desde la perspectiva de las medidas regulatorias de la materia y las reglas de procedimiento con el fin de identificar modelos regulatorios apropiados. A partir de reflexiones analíticas sobre la información obtenida de fuentes y literatura relevantes, la autora analiza las disposiciones de la normativa de la UE que crean patrones de marco legal y protección de patentes desde el punto de vista de consolidar las novelas de legislación y práctica sustanciales y procesales. Los resultados se presentan en un sistema y comparación de los regímenes de protección - actuales y anteriores - de los derechos de patente en la UE.Así, la importancia teórica y práctica de los resultados obtenidos viene determinada por el hecho de que el lector dispondrá de información científica moderna sobre el estado de la legislación de la UE en el campo en estudio, que contribuirá a la comprensión de la brecha (o su ausencia). en los logros de investigadores y profesionales en Rusia y en el extranjero en esta área.
\end{abstract}

Palabras clave: Unión Europea, protección de la ley de patentes, Convenio de Patente Europea, Tribunal Europeo de Patentes, Rusia.

\begin{abstract}
This article aims to explore the developments in the legal protection of inventions in the European Union (EU) from the perspective of regulatory measures on the matter and the rules of procedure in order to identify appropriate regulatory models. Based on analytical reflections on the information obtained from relevant sources and literature and dialectic method, the author analyzes the provisions of the EU regulations that create patterns of legal framework and patent protection from the point of view of consolidating the novels of substantial legislation and practice and procedural. The article is based on analytical reflections on information taken from sources and literature and descriptive approach to the legal regulations in the field under study. The results are presented in a system and comparison of the protection regimes - current and previous - of patent rights in the EU. Thus, the theoretical and practical importance of the results obtained is determined by the fact that the reader will have modern scientific information
\end{abstract}


on the state of EU legislation in the field under study, which will contribute to understanding the gap (or your absence). on the achievements of researchers and professionals in Russia and abroad in this area.

Keywords: European Union, European Patent Convention, European Patent Court, Russia.

\section{Introduction}

The word "invention" (Erfindung) represents in people's minds a reality that exists regardless of the law, being perceived not as a legal category, but as a natural-technical one; creating of inventions, as well as their use was not always linked to legal regulation. Patent law uses this term in a narrow (as compared to the common use) and specific sense, implying that only a patentable invention is legally relevant, so the term is used in the legal literature to describe the subject matter of legal protection (Thompson \& Woerter, 2020).

Several conventions adopted in the 1960-70s unified numerous patent law issues in Western Europe. In 1963 in Strasbourg the Agreement on the unification of certain provisions of patent law was signed. In 1973, the Munich Convention providing for the granting of a European patent was adopted, while two years later the Luxembourg Convention introduced a single "European patent". Because of these agreements and the changes in national legislation based on them, the patent law of France, Germany and England has largely lost its former specificity (1980). Thus, for example, Germany changed its pre-1980 legal rules for the protection of inventions that were related to the establishment of types of protection, internal priority, recognition of indirect patent infringement, as well as the cancellation of benefits relating to novelty and publication (layout) of examined applications, etc. For example, according to A. Krieger, the aim of converging the approaches of the national legal order was to eliminate the different validity periods of patents granted by national and European patent office's (1981) (Halla \& Helmers, 2019).

So, the goal of this article is to study the novels of legal protection of inventions in the European Union (hereinafter referred to as the EU or the Union) from the standpoint of subjectmatter regulatory measures and procedural rules in order to identify appropriate regulatory models. In terms of the chosen approaches we proceed from the need, firstly, for the protection of intellectual rights by patents themselves, and secondly, for the improvement of its mechanisms, i.e., the emergence of novels caused by changes in the life of an individual and society (Grzegorczyk, 2020). 


\section{Literature review}

This study is aimed at reviewing the novels of legal protection of inventions in the EU from the subject-matter regulatory measures and procedural rules perspective. The present research is executed based on the expert data from the papers of both Russian and European researchers. The author proceeds from the fact that patent law protection has now priority over ideas of free use of inventions and other results of individual creative activity, both at a level of normative acts and documents, and in the minds of the overwhelming majority of common people, scientists, practitioners and others. The following authors are to be mentioned: Lucarelli \&. Radaelli (2004), Seville (2016), Schovsbo, Riis, \& Petersen (2015), Walsh (2015), Callens \& Granata (2020), Belda, (2014), Belikova (2019), etc. These publications highlight the different facets of the issue of patent protection of inventions in the EU, but they are not sufficiently comprehensive. This gap was at least partially filled by this paper.

\section{Materials and methods}

This article is based on analytical reflections on information taken from sources and literature, the provisions of EU regulations creating patterns of legal regulation and patent protection from the point of view of establishing in them the novels of subject matter and procedural legislation and practice are analyzed. Methodology is based on materialist dialectics and consists of collecting data through analysis of the legal acts and documents (Communication from the Commission to the European Parliament, 2007; European Communities Council, 1976; Working Party on Litigation, 2004, EPC, 2010) and descriptive approach to the legal regulations in the field under study likewise reflective practice. Thus, the method of systematic analysis and reflection on the ideas provided in the aforementioned articles, book chapters, etc., along with such operations as induction and deduction, is used in the course of consideration of the provisions of EU normative acts and documents in the field under study; methods of formal and dialectical logic help to understand the relationship between the needs of patent law participants and normative regulations; the materialistic view of the processes and phenomena of the external world as a whole makes the study proceed from the fact that the free use of works as opposed to their patent protection does not yet provide adequate protection (due to the level of legal understandings, lack of appropriate culture and patterns of behavior, habits, etc.). 


\section{Results}

The results obtained in the study and the undertaken analysis show and make clear the following:

1. The existing EU-wide level of patent protection makes it possible to point out a defining role of the international rules, which set the limits of the regional legal regime (e.g. the European Patent Convention). Thus, The mechanism of essentially international agreement on the Single Patent Court of 2013 (The Council of the European Union, 2013), concluded with the aim to create a judicial system of unified resolution for patent disputes, seems to be conceptually based on the EU legal order; otherwise, it would be impossible to ensure uniformity in the protection of patent rights based on a unitary patent, that may be illustrated by Figure 1.

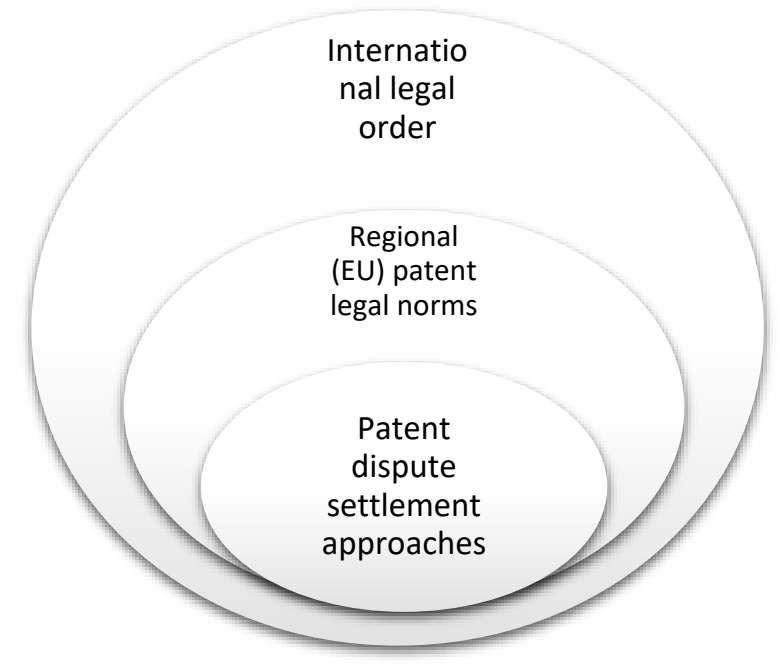

Figure 1. Interrelation of international and regional (EU) legal orders and way of dispute settlement

2. At the same time, if at the initial stage the results of the regional rulemaking were rooted in the agreement establishing the EU, which provide a basis for further development (1957 Treaty of Rome, etc.), the subsequent period has transformed them into domestic legal models (e.g. national patents), and now again into regional, EU legal models (e.g. unified patent, Single Patent Court, etc.) (Figure 2). 


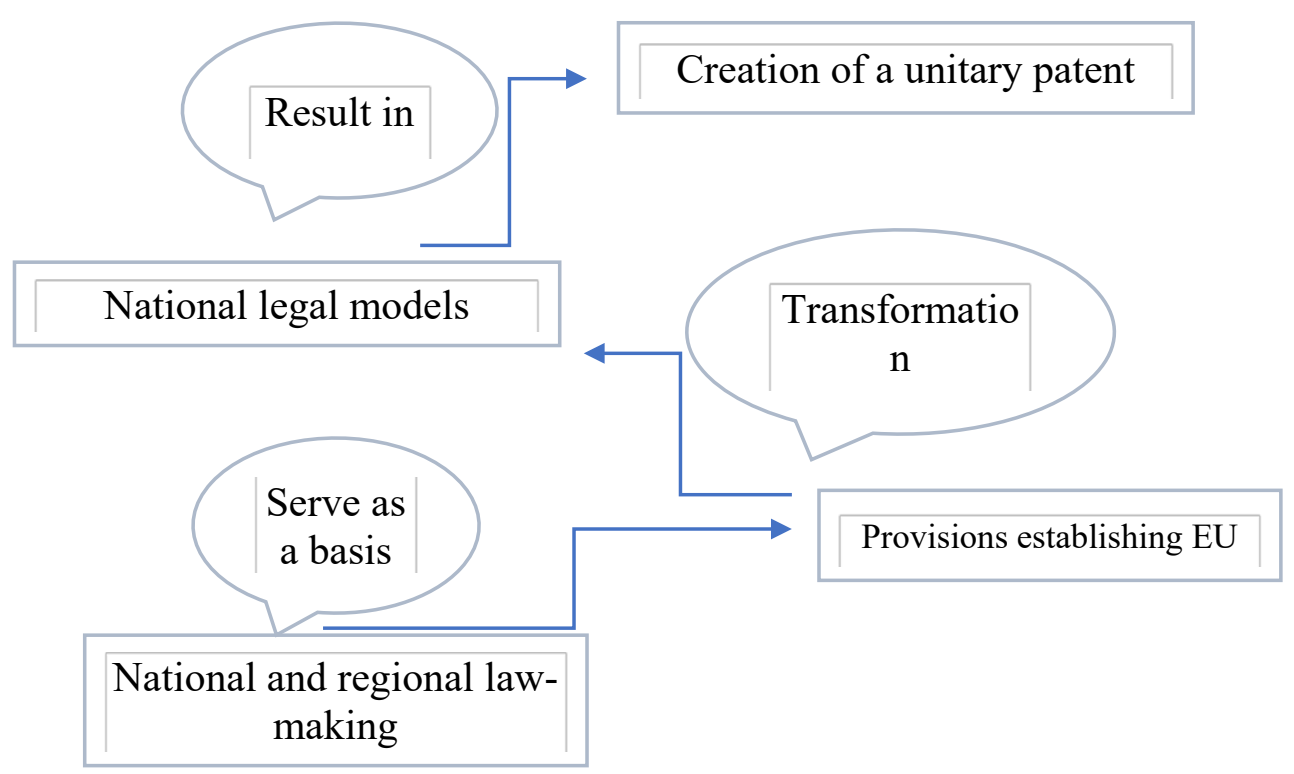

Figure 2. Interrelation between regional (EU) and national patent legal norms

3. The parallel development of the European patent system with the national systems is:

- First, a source of uncertainty and disagreement in the patentability criteria, the place of resolution of patent disputes and the division of powers between national and European patent offices, as the focus of the current European patent system on simplification of formalities has resulted in numerous patents for the same invention, obtained in different EU countries; this "clogs up" the space of scientific research achievements due to the continuing diversity of provisions of national patent legislation.

- Second, a promoter of further centralization of patent law in the EU as a result of creating a Community patent and a unified system of administration of justice operating throughout the EU.

- Third, furthermore centralized for all EU countries patent infringement and challenge under the unitary patent system, countering patent infringement (contestation) individually at the national level of each country under the European patent system, certainly strengthens the unifying effect and centripetal forces that are so important for the viability of any supranational community (union, organization) (Figure 3). 


\section{Unitary patent system encourages the centralization of patent legal norms}

*by creating a patent community and

*a unified system of administration of justice
Multiple national patent systems lead to:

*differences in criteria of patentability,

*separation of powers between EU patent offices and EU countries,

*emergence of many national patents,

* individualized countermeasures against infringement of patents and, thus, *urgent need of centralized recognition of patent infringements and patent disputes

Figure 3. Some stumbling stones of parallel development of the European patent system with the national systems.

\section{Discussion}

Patent law protection in the EU is implemented under two types of protection that are not based on the legal provisions of the Union:

- The first type of protection is provided by national patent systems;

- The second one is implemented in the framework of the international legal system of protection based on the so-called European Patent Convention of 1973 (further will be referred to as EPC) that created European patent system (Belikova, 2011).

The European Patent Office (EPO) was established based on the provisions of the EPC with its seat in Munich. It was desirable to find something common between the EPC system and the system of Community Patent Regulations (Van Overwalle, 2001; Latham \& Watkins, 2003). In other words, the purpose of the patent system proposed in the Draft Regulation on Community patents was not to replace national patent systems and the European Patent System, but to act on a par with them: the inventor would be able to choose the most appropriate type of patent protection for him. Thus, the EU's jurisdiction, which is external to the Community patent, would be transferred to the domestic jurisdiction. As such, it was feared that the introduction of a Community patent would only increase legal uncertainty (Walsh, 2019) (Fig. 4).

The Regulation on the applicable translation arrangements provides a translation procedure for the $25 \mathrm{EU}$ countries which have recognized a European patent with unitary effect: applicants will also be required to provide a translation into one of the three official languages of the EPO (English, French or German), since only a unitary patent which has been published in one of the three official languages of the EPO - English, French and German - and for which 
the claims have been translated into the other two languages in accordance with Article 14 (2000) of the EPC is not required.

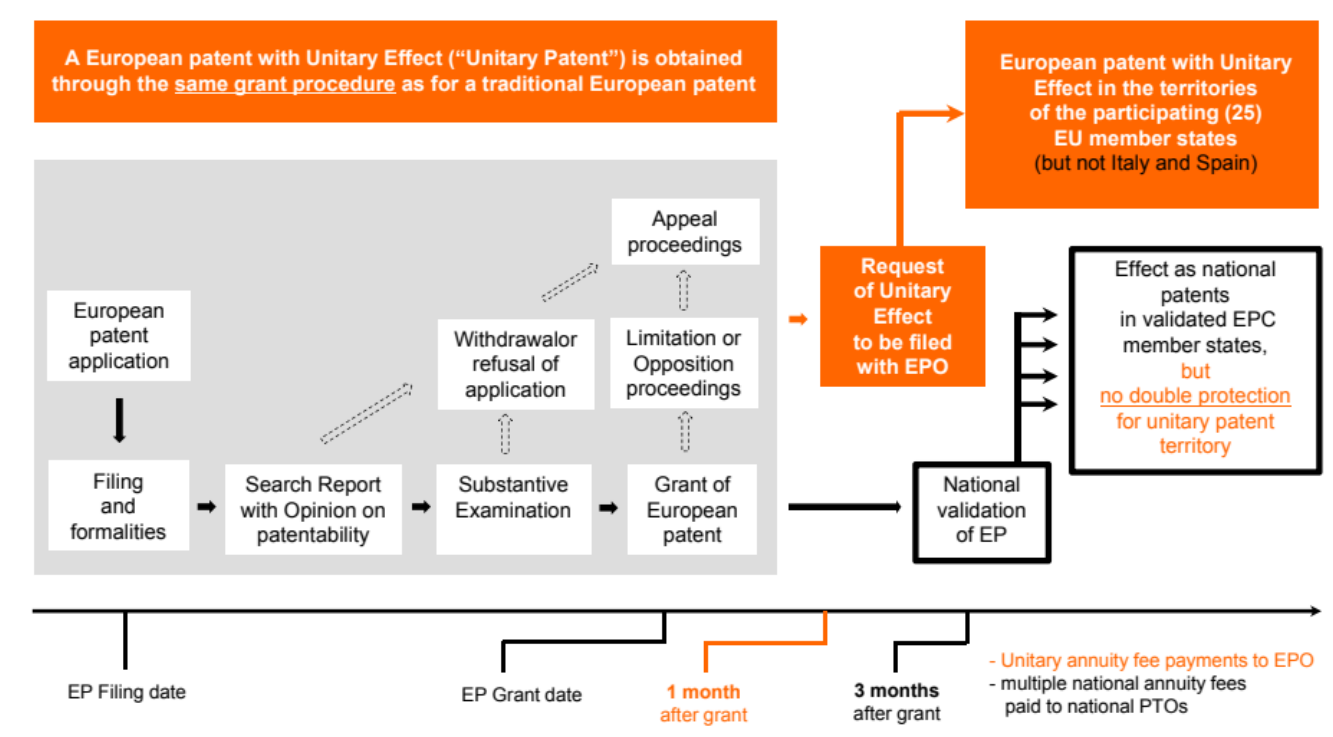

Figure 4. Unitary patent grant procedure (Massaro, 2014).

A patent holder who suspects a violation of his or her right must provide, at the request of the alleged infringer, a full translation of the patent into the official language of the EU country wherein the alleged infringement has taken place or alleged infringer is residing; ensure that the patent is fully translated into the official language of the courts of other European countries that hold the unitary patent, which may be involved in legal proceedings; bear the costs of these translations.

These translations will be necessary until high-quality machine translations in all EU languages are available. In this format, the Independent Expert Committee, after 6 years from the date of filing and every 2 years thereafter, should evaluate the ability of machines to translate patent applications and the specifications contained therein in a high-quality manner, and the European Commission should report to EU governments on the basis of the first and subsequent evaluations by this Committee. The history of this issue is that it was not possible, during the discussion of the Draft Regulation on Community patents to determine the time limit within which such translation should be carried out, since a Community patent should not come into force if the translation into the languages concerned is not carried out within the prescribed time limit (Belda et al., 2014). 
It was proposed that the Court of Patents would be composed of seven judges appointed for 6 years by the Council of Ministers of the EU, taking into account their knowledge and experience in the field of patent law, after consultation with a deliberative committee of candidates submitted by the Member States. Once appointed, the judges would elect a chairperson from among themselves for a 3-year term that may be re-elected. The Court sits collegially with three judges, sometimes with an extended membership, sometimes alone. The language of the proceedings is the official language of the country in which the defendant is domiciled.

The origins of this initiative should be found in the work of the Intergovernmental Conference held in Paris on June 25, 1999. At that Conference, the EPC countries established a Working Group on Litigation. The tasks of the Working Group were: firstly, to present the draft text of the additional protocol to the EPC, which will establish an integrated judicial system and consolidate uniform rules of procedure and create a common court of appeal; secondly, to determine the conditions under which a unified (judicial) office will be created and funded, which will be able to appeal to the parties, challenging the validity of the patent and patent infringement.

In September 2005, a subdivision of the Working Group met to adopt as Draft Agreement on the Establishment of a European System for Litigation the relevant provisions of the Directive on the Exercise of Intellectual Property Rights of April 29, 2004, discussed above. The result of the work was presented to the members of the Working Group on December 14, 2005, for information, many of its provisions were subsequently incorporated into the 2013 Agreement (The Council of the European Union, 2013), which is currently undergoing ratification.

In this context, in a Communication from the Commission to the European Parliament and the Council dated April 3, 2007 "On the promotion of the patent system in Europe" (2007), a combined approach was adopted:

- The main provisions of the Draft Agreement on Litigation of the European Patent, designed to create in the context of the EPC a single system for litigation of the European Patent, namely the European Patent Judiciary (EPJ), which will consist of the Court of First Instance, the Court of Appeal and the Registration Chamber, and the Administrative Committee;

- The idea of creating a "communitarian" jurisdiction in the form of a special Community court with the procedures based on Treaty for litigation on European and Community patents, originally proposed by the Commission. 
The Communication also noted that the current European Patent System needed to be improved as it is currently more expensive than the US and Japanese patent systems; any disputes arising out of and in relation to the European Patent granted by the European Patent Organization (EPO) can be brought before national courts, which creates legal uncertainty and prevents the normal conduct of business involving the use of patented inventions in relation to: high litigation costs; lack of clarity in the submissions of national judges; and the impossibility of legal proceedings.

Following this approach, the EU Commission adopted a Recommendation to the Council on March 24, 2009 (2009) that noted that the Commission had initiated work aimed at concluding an agreement on the establishment of a Unified Patent Litigation System (UPLS) empowered to hear and settle cases of infringement and validity of existing European patents and future Community patents. This system will be created based on an agreement between the EU member states and non-EU member states of the EPC (2009).

The Administrative Committee will appoint the judges. Some of them must be qualified as lawyers and others as technical judges. The judges must be composed of at least one technical judge, an expert in each technical field. In cases provided for in the UPC Agreement or the UPC Statute, the judges will be distributed among divisions by the UPC President, for example at the request of a local or regional division of the Court in the event of a counterclaim for the revocation of a patent. No judge may hold any other paid or unpaid position, but may exercise judicial functions at the national level.

\section{Conclusion}

In conclusion, of course, it is necessary to note the progressive development of patent and legal protection at the EU level. Its prospects are also interesting. Certainly, this development has faced both difficulties on its way (some of them remained unsolved) and the circumstances, which were favorable for such development. As always, this process is the result of subjectively and objectively determined development.

At the same time, when a European unitary patent is introduced, applicants have significant advantages in patenting if they are interested in covering a large number of EU countries, while traditional European patents will continue to coexist with a unitary patent. The results of the creation of a single patent court as a single court whose decision is recognized by all countries where a unitary European patent is in force, we will see its pros and cons in the end. 


\section{Acknowledgements}

The publication has been prepared with the support of the "RUDN University Program 5-100".

\section{References}

Belda, I., Penas, G., Marquina, D., Santos, A. (2014). Analyzing the impact of the European unitary patent system on worldwide biotechnology. Trends in Biotechnology, 32(8), 394-396. doi: 10.1016/j.tibtech.2014.06.003

Belikova K.M. (2019). Legal aspects of the Brazilian government in stimulating the generation and implementation of scientific information as innovations. Amazonia Investiga, 8(20), 91-97.

Retrieved

from: https://amazoniainvestiga.info/index.php/amazonia/article/view/67

Belikova, K.M. (2012). Legal Framework of the Competition Environment within BRICS Countries: Novels in the Brazil Legislation. Vestnik Mezhdunarodnykh OrganizatsiiInternational Organisations Research Journal, 7(4), 239-247. Retrieved from: https://www.hse.ru/en/mag/vmo/2012-7-4/70752367.html

Callens, P., Granata, S. (2017). Ch. VI. Language Regime of the Unitary Patent. The Unitary Patent and the Unified Patent Court. Wolters Kluwer.

Communication from the Commission to the European Parliament and the Council of 3 April 2007 - Enhancing the patent system in Europe. Retrieved from: https://eurlex.europa.eu/LexUriServ/LexUriServ.do?uri=COM:2007:0165:FIN:EN:PDF

Community patent.

Retrieved

from: http://europa.eu/legislation_summaries/internal_market/businesses/intellectual_propert y/126056 en.htm

Council Regulation (EU) No 1260/2012 of 17 December 2012 implementing enhanced cooperation in the area of the creation of unitary patent protection with regard to the applicable translation arrangements. OJ L 361. Retrieved from: https://eurlex.europa.eu/legal-content/EN/TXT/?uri=celex:32012R1260

EPC 2000. (2010). Revision of the European Patent Convention. Retrieved from: https://www.dehns.com/cms/document/epc2000_revision_of the epc.pdf

European Communities Council. (1976). Council Convention for the European Patent for the Common Market (Community Patent Convention). Official Journal of the European 
Communities,

$1-28$.

Retrieved

from:

https://eur-

lex.europa.eu/LexUriServ/LexUriServ.do?uri=OJ:L:1976:017:0001:0028:EN:PDF

EU unitary patents - translation arrangements. (2017). Retrieved from: https://eurlex.europa.eu/legal-content/EN/TXT/?uri=legissum:4300390

Grzegorczyk, T. (2020). Managing intellectual property: Strategies for patent holders. The Journal of High Technology Management Research, 31(1), 100374. doi: 10.1016/j.hitech.2020.100374

Halla, B.H., Helmers, C. (2019). The impact of international patent systems: Evidence from accession to the European Patent Convention. Research Policy, 48(9), 103810. doi: 10.1016/j.respol.2019.103810

Khanina, K.V. (2007). Harmonization of norms regulating the use and protection of creative activity results in the European Union. Extended abstract of dissertation. Moscow. Retrieved from: http://www.law.edu.ru/book/book.asp?bookID=1274652

Krieger, A. (1981). Das neue deutsche Patentrechtnach der Harmonisierungmit dem europaischen Patentrecht - eine Ubersicht. GRUR Int., 5, 284.

Latham \& Watkins. (2003). Client alert. Retrieved from: http://www.lw.com/upload/pubContent/_pdf/pub790.pdf

Lucarelli, S., Radaelli, C.M. (2004). The European Convention: A Process of Mobilization?. South European Society and Politics, 9(1), 1-23. doi: 10.1080/13608740410001681370 Massaro, M. (2014). Patenting in Europe: entrance to the European market. Retrieved from: file:///C:/Users $/ \% \mathrm{D} 0 \% 9 \mathrm{~F} \% \mathrm{D} 0 \% \mathrm{BE} \% \mathrm{D} 0 \% \mathrm{BB} \% \mathrm{D} 1 \% 8 \mathrm{C} \% \mathrm{D} 0 \% \mathrm{~B} 7 \% \mathrm{D} 0 \% \mathrm{BE} \% \mathrm{D} 0 \% \mathrm{~B}$ 2\%D0\%B0\%D1\%82\%D0\%B5\%D0\%BB\%D1\%8C/Downloads/Mariella\%20Massaro. $\% 20$ Unitary $\% 20$ patent $\% 20$ protec _pdf

Patents: Commission sets out next steps for creation of unified patent litigation system. IP/09/460. (2009). Retrieved from: http://europa.eu/rapid/press-release_IP-09$\underline{460 \text { en.pdf }}$

Proposal of 1 August (2000) Proposals for a Council Regulation on the Community patent. Retrieved from: https://eur-lex.europa.eu/legalcontent/EN/TXT/PDF/?uri=CELEX:52000PC0412\&from=EN

Proposal of 2 December 2003 for a Council Decision establishing the Community Patent Court and concerning appeals before the Court of First Instance [COM (2003) 828 final - not published in the Official Journal]. 
Proposal of 23 December 2003 for a Council Decision conferring jurisdiction on the Court of Justice in disputes relating to the Community patent [COM (2003) 827 final - not published in the Official Journal].

Recommendation from the Commission to the Council to authorise the Commission to open negotiations for the adoption of an Agreement creating a Unified Patent Litigation System. (2009). SEC (2009) 330 final. Retrieved from: https://ec.europa.eu/transparency/regdoc/rep/2/2009/EN/2-2009-330-EN-F-0.Pdf

Regulation (EU) No 1257/2012 of the European Parliament and of the Council of 17 December 2012 implementing enhanced cooperation in the area of the creation of unitary patent protection. OJ L 361. Retrieved from: https://eur-lex.europa.eu/legalcontent/EN/TXT/?uri=celex:32012R1257

Regulation 469/2009 of the European Parliament and of the Council of the European Union of 6 May 2009 on supplementary certificates of protection for medicines. Retrieved from: https://base.garant.ru/70417696/

Schovsbo, J., Riis, T., Petersen, C.S. (2015). The Unified Patent Court: Pros and Cons of Specialization - Is There a Light at the End of the Tunnel (Vision)?. IIC, 46, 271-274. doi: 10.1007/s40319-015-0331-2

Seville, C. (2016). EU Intellectual Property Law and Policy. Edward Elger Publishing. doi: $10.4337 / 9781781003480$

Single EU patent boosts intellectual property protection and cuts related costs. (2014). Retrieved from: https://eur-lex.europa.eu/legalcontent/EN/TXT/?uri=legissum:2406030201_1 (data retrieved: 01.11.2019)

The Council of the European Union. (2013). Agreement on a Unified Patent Court. Official Journal of the European Union, 1-40. Retrieved from: https://eurlex.europa.eu/LexUriServ/LexUriServ.do?uri=OJ:C:2013:175:0001:0040:En:PDF

Thompson, M.J., Woerter, M. (2020). Technological forecasting and social change competition and invention quality: Evidence from Swiss firms. Technological Forecasting and Social Change, 156, 120023. doi: 10.1016/j.techfore.2020.120023

Unified Patent Court. (2017). Retrieved from: https://eur-lex.europa.eu/legalcontent/EN/TXT/?uri=legissum:2406030201_2

Van Overwalle, G. (2001). The proposal for a Council Regulation on the Community patent. Intellectuele Rechten - Droits Intellectuels, 6, 202-206. Retrieved from: https://ssrn.com/abstract $=1721074$ 
Walsh, K. (2019). Promoting harmonization across the European Patent System through judicial dialogue and cooperation. IIC, 50, 408-440. doi: 10.1007/s40319-019-00808-X

Working Party on Litigation. (2004). Draft Agreement on the establishment of a European patent litigation system. Retrieved https://www.ipeg.com/_UPLOAD\%20BLOG/EPLA\%20agreement_draft.pdf 